\title{
HOME ALONE WITH TECHNOLOGY: AN INTERVIEW WITH NEIL POSTMAN
}

Norman Clark

Neil Postman is a cultural critic of communication and chair of the Department of Communication Arts at New York University. He has written several books on the cultural and social consequences of communications technology, including Amusing Ourselves to Death (1985) and Technopoly: The Surrender of Culture to Technology (1992). As a dedicated educator, his works often feature the role education may play in rescuing us from our obsessive interest in technological "advancement." And as a dedicated educator, he willingly agreed to be interviewed when he was visiting in Iowa City. I spoke with him on a Saturday evening, just after he had witnessed the Iowa Hawkeye football team lose.

In your book Amusing Ourselves to Death, you said that "the medium is the metaphor" instead of "the medium is the message." You then argued that our cultural metaphor for television was entertainment. Is this still our operating metaphor for television, or is there a different metaphor?

I do think so, and I think the basic reason is that it is a visual medium. I mean, people watch it, and what they like to watch are dynamic and exciting and fastmoving images. So television is not very good as a medium for the expression of complex ideas. It's not very good as a medium for conveying a sense of historical continuity. Its grammar especially has almost nothing but a present tense. Everything is experienced as if it were happening right now.

Events, rather than processes.

Yes, and even something that's on videotape, you would normally say: "This videotape was made July 18, 1991." Otherwise, people would believe it is happening now. So its sense of instancy and presentness and its visual nature make it essentially a medium of aesthetic discourse. And that means, as it turns out in America, it's largely entertainment. Of course it could be used for serious theater, and it once was before you were born. From 1948 to 1952 or 53, when all television was live, there were something like 1500 original dramas written for 
television. So it certainly could be used as a medium for the expression of theatrical ideas. But it's still-even more so-an entertainment medium par excellance.

Do you think that with the trend toward interactive television it will become more so, or could interactive television be used for things other than entertainment?

Well, the one thing that television is very good for that's not exactly entertainment is "history in the making." I mean, when television showed us what was happening in Tiananmen Square, Beijing, or that earthquake in San Francisco just before the World Series game started, where the commentators don't even know what's happening or what's going to happen, the idea of seeing the trembling moments of history, television is very good at that. But we don't get very much of it, though we used to get more of it. Television is so much a part of the economy now, that is to say it is controlled by advertising, that it's not likely that we'll get too much of that in the future since advertisers don't like programs that are uncontrolled or have uncertainty in them. They will allow a Penn State-Iowa football game because there is certainty that Iowa will lose. (laughter) But on that point, sports is a big thing for advertisers. One could say that there's uncertainty in the outcome, but that's a superficial sense of uncertainty. The whole thing is packaged so that everything that really occurs there is controlled. So while television is awesome in its capacity to actually show instantaneously something that's happening in the real world, I don't think it's going to be used much for that because advertisers want to make sure that the programming is entirely predictable.

What metaphor would you use for the Internet, a medium that came onto the scene after you wrote Technopoly? Is it still entertainment, or something else?

Of course there is a strong tendency for people to use it as simply another outlet for entertainment, but there's no doubt that people use it as a source of information gathering and information dissemination. But in my view, which you would know if you read Technopoly, this is not what people need. Here's the way I look at it. In the nineteenth century, let's say in the 1830 s, a message could only move as fast as a human being could, which was about 30 miles an hour on a fast train, and language was about the only medium through which messages could be communicated. So, early in the nineteenth century humanity set out to solve this problem. The problem could be stated this way: how to get more information to more people faster and in diverse forms. We began that quest, let's say in the $1840 \mathrm{~s}$, with the invention of telegraphy and photography. And for a hundred years after that, we continued to solve that problem.

If you and some of your colleagues would check out what inventions were made in the nineteenth century you might come to the same conclusion I have, which is that there was more technological innovation in the nineteenth century than even in the twentieth, and that there was more in the nineteenth than there is likely to be in the twenty-first, but we'll leave that point aside for the moment. The fact is, from the 1840 s and about a hundred years forward we addressed the problem of how to get a lot of information to a lot of people faster and in diverse 
forms, and we solved that problem. And I want to emphasize that point: we have solved that problem.

Now in solving that problem, as always happens with technology, we created another problem, which is what I called in Technopoly "information glut," unprecedented in human history. Prior to this, all cultures suffered in one way or another from information scarcity. People needed information to solve serious problems of their material and symbolic world. Now we solved that problem. The Internet, and other uses of computer technology, simply seem to me to be distracting us from the problems we now have to solve.

Let me put it this way: if there are children starving in Somalia, it's not because we have insufficient information. We already know enough to feed everyone in the world. If we don't feed them it's not because we don't have enough information. And if crime is rampant in the streets of New York and Detroit and Los Angeles, it's not because we don't have enough information. If the ozone is being depleted and the rain forest are disappearing, more information is not going to solve that problem. There's another kind of problem we have to solve. You can call it technological, social, whatever-but it has nothing to do with insufficient information. As a matter of fact half the marriages in the United States now end up in divorce I'm told. More information doesn't solve that problem. There's something else that is a problem, and information glut just distracts people from facing up to these other issues.

So when you talk to people, especially young people who grew up in California and then moved to Iowa, all they want to talk about is interactive television, the Internet, and other modern methods of generating and manipulating and disseminating more and more information. And that's because their brains are addled. (laughter) This is why I wrote a book like Technopoly, and in my newest bookI'm sure you're going to go to Prairie Lights Bookstore to buy a copy, maybe even one for your wife so you can read it at the same time and grow closer to each other-I also emphasize this point. The problem in education doesn't have anything to do with how to get more information to children faster-it has nothing to do with that. But Americans don't like to face up to this problem, because we love technology, and we know how much technology has done for us in helping us to become a world power. We have what de Tocqueville called "a lust for the new," and we have a lust for new technology.

To put it plainly, I think the Internet is something like power steering or cruise control in cars. I mean, not that it's not useful, but once you invent the basic car, you've got it. Now these things are useful, and the automobile companies add them on to the cars and then they convince consumers that they absolutely have to have them. I'm not saying that they're completely useless-of course, they're not. But the Internet doesn't help us address the problems that we need to address.

You briefly mentioned that the problems could be called psychological or social...

Take economics. Our cities are crumbling, our government seems in fact to have given up on the cities, it may even have given up on the under class, we can't even 
get health insurance for 35-40 million people - this is unbelievable, isn't it? There's 35 or 40 million people who have no health insurance, and even those who have health insurance, if they really get sick, can be financially wiped out. So this is the greatest imperial power on the planet and everyone is talking about the Internet! We're polluting our air, we're making our rivers toxic, the population is turning to tribalism-the blacks want schools just for the blacks, the Asians just for the Asians, the Hispanics for the Hispanics, people don't even think of themselves anymore as Americans. Sports is probably the only thing that unifies Americans for two hours, although why people would root for the Iowa Hawkeyes I don't know but they do. (laughter)

So these are problems, and I'm not the best person to ask to enumerate all of them. There are many professors at the University of Iowa in economics, in political science, in sociology, who could really give you a run-down of the issues we have to address as Americans if we really want to go into the third millennium with some hope and some vitality. The Internet and computer technology are just distractions. What would happen if all of the brilliant young people, and even people smarter than both of us, turned their attention to these problems and away from the issue of how to get more information faster to more people? Maybe we could actually solve some of these problems! We would develop all sorts of possibilities for our future. People have always relied on playwrights and musicians and novelists and poets to give them new visions, new symbols to live by and to find meaning in life. But we're short on these people because all they want to do is play on their computers. I know you don't agree with me because your brain is addled. (laughter)

I do agree with you that too much emphasis is focused on the Internet as a phenomenon. But I think there are ways that it can be used as a tool that are helpful: for instance, community networks. Local communities are using the Internet as a way to augment or supplement or even, in places where they've been totally wiped out, fill the void left by the decline of local community newspapers. So a community can post information about local events, senior citizens can find out...

This is a new conception, and a very impoverished one, of community.

Well, I'm not talking about virtual community. This is where a local, geo-political community is trying to rebind people in the community together, and they're using the Internet to draw people into local activities and politics.

If that can happen, then I'll be the first person on-line to cheer, as long as we're clear on what we mean by community. I was at a conference recently in Albany, New York, and heard two young people from Cornell-not the Cornell in Iowa, but Ithaca - and they were discussing the uses of computers for creating a sense of community. And the young man who was most enthusiastic about this actually gave the following example. He talked about a man who was dying of cancer, and he said this man was able to communicate with his friends all over the country, and it gave him some comfort in his last months. The question I asked this fellow 
was, "Didn't this guy have any friends where he lived? Didn't he have any family, people to hold his hand and talk to him face-to-face?" If a man is dying, you would say this is what a man needs. Not to get on a typewriter and talk to someone in Brisbane, Australia that he's a friend or an acquaintance with and say, "oh, this is community."

Now if it gave the man some comfort, who can speak against it? But the fact that the man didn't have anyone around in his last days, that's the tragedy. Now, you can say, "maybe community is gone in America, so that all we have left is to type messages to each other in cyberspace." I suppose if we have nothing left, maybe that's better than nothing. [But] when you talk about it, you should be weeping, you should be crying, not smiling.

What I find positive is local communities that are using the Internet to get people involved in their communities...

I know what you're saying. If that happens-if you can use something like this to actually get people to meet with each other, to be co-present, face-to-face, talk to each other, touch each other-then I'm all for it.

A lot of studies have been done on newspaper usage, and what they've found is that the local papers aren't often read by the people the community needs the most: the people with the most resources, either economic, intellectual, or political. Those people are reading a lot of outside news, and are concerned with outside affairs. So the developers of community networks are trying to use the Internet, which most of the people with more power have access to, to draw them back into the local community.

I'm with you on this. If it could be used for that larger, more significant purpose, I would be for it. But I don't think we should put all of our hopes on that sort of thing.

You talked a lot about information glut. One potential for the Internet-contrary to people who say it's going to increase information load-is to control and filter information for us. For example, there are programs that will seek out news from a variety of sources that is of interest to you. You would enter into this program what your interests are, where you live, where your family lives, what your profession is, and so forth. This program would go out and find news of importance to you based on the information you entered.

I can see your point, except that in itself it does tend to increase fragmentation. After all, a curriculum in school is based on the notion that we have a common culture. And this is bad, you see, because you haven't read Don Quixote.

Actually, Ihave.

I take it back. But we used to have-I'm not talking about a canon necessarilyan idea that (recognizing that we're different from each other and that every person would have some interest that perhaps no one else has) in a culture-if we're going to have a culture - there have to be common points, things that everyone 
should know about, everyone should be interested in. Now some people suggest, like Lewis Perelman in his book School's Out, and even Diane Ravitch, the former Assistant Secretary of Education, that computer technology almost renders school irrelevant, because you can just have the computer at home and call up anything you happen to be interested in. I think this just tends to increase the sense of isolation and fragmentation in our culture, so it could be very dangerous.

Sure. I would agree that if everyone came to work the next day and they've all read different news, they have less to talk about. You could rapidly get a completely fragmented culture. But as an augmentation device, it may be of use.

I like that phrase. Maybe we should start using it: the computer as augmentation device. By the way, in this month's issue of Geo magazine, which you won't be able to read unless you read German, I have a debate with Bill Gates on these issues. But it may be published by Fortune magazine.

In Technopoly you said that one of the problems of a technopoly is that social institutions don't control or filter information so technology does it, or technology starts to do it so social institutions back off and let technology have its way. What do you think of recent trends in congress to put more restrictions on the Internet and other forms of communication? Is this an attempt to take some control back from technology, or is it a case of too little too late?

It probably can't really be done. For example, you mean restrictions on pornography?

Sure, that's one area.

Well, I just don't see how it could be done. Is it even technically possible?

No, probably not. One of the larger dilemmas right now is how the U.S. can regulate pornography on the Internet when it's an international network of computers.

You know, it's somewhat similar to the problem that the European countries face with television. In the early days of television, the government controlled the content of television. There were no advertiser-supported stations. But with the development of video technology — satellites, VCRs, cable-it became impossible for governments to control. So now in France, and Italy, Germany, the Netherlands, and England of course, it's more like America. And I think it's somewhat the same situation with the Internet-that it's too international for it to be controlled.

You argued that technologies change what our words mean. For example, to a certain extent television changed what "information" meant. What are some words now that you think are changing because of current technologies?

That's a very interesting question. Take this World Series game. If [Kenny] Lofton steals home, and you don't see it the first time, all someone has to do is tell you, "Lofton stole home," and you can turn around, and then you'll see it four 
more times because they'll do a replay. So that actually does change the meaning of "see," and really "reality." I went to a ball game at Shea Stadium in New York this summer, and the Mets second baseman hit a home run, and I remember thinking, "I have to see this again." Then I realized, this is reality! In reality, things don't happen again. But of course they've accommodated this new conception of reality at Shea, as in almost all ball parks, I guess, by having a huge television screen so that you can see it again four more times.

So all sorts of very important words get changed, and there's nothing inherently dangerous about this if people are aware of what's going on. But what very often happens is that the meaning of the word is altered, but people are not so much aware of it. And they begin to use a word, say like "community" on the Internet, as if it means the same thing. I just reviewed a book for the Los Angeles Times, it's a pretty good book called The Electronic Republic by Lawrence Grossman who was head of NBC news and also president of PBS. He says-I had to point this out in the review and it's a good answer to your question-with the computer technology now, combining it with telephone lines and so on, we can have participatory democracy the way the Greeks had it in Athens in the fifth century B.C. So now you can have plebiscites, for example, on everything. Like NAFTA. Congress wouldn't have to vote on it. You just argue your case for NAFTA and against it and all of the people go to their computers and make a vote. On troops going to Bosnia, people make a vote. So he says that this is participatory democracy. The days of representative democracy are over, and it'll be just like 5,000 Greek philosophers getting together on a hill outside of Athens, arguing and making decisions. Well, there's quite a difference between that meaning of participatory democracy in Athens and what it would mean for 250 million Americans. Basically what he did was use the phrase "participatory democracy" without examining in any depth how its meaning would be different in the situation he described from the meaning of the term not only in Athens but also in Massachusetts in the late eighteenth century.

I'm just picturing people sitting in front of their computers all day long voting on every bill that comes up before the House. Pretty soon, there'd be nothing done.

If you take the term "defensive line," and you watch Iowa play, their conception of a defensive line has nothing to do with a normal person's meaning of a defensive line. (laughter)

On this point-it's very interesting and it goes beyond discussing how technology alters language, but social change generally-yesterday I read from my book at Prairie Lights, and afterwards two young women came up and had some questions. One of them kept using the term Native American to refer to what we used to call Indians. I took a little exception to this term, because I was born in America and I've always thought of myself as a Native American. But social change usually does require the invention of new words, or taking some old word and infusing it with a new meaning. Now that's part of the process of social change, just as I said before it's part of the process of technological change. It's not that I'm saying we must hold this back, except to the extent that we show 
some awareness of its happening, so that we might say, "Well you know, I'm not against language changing, but there are some changes I don't think we should make just yet, because there are some older meanings that I still think we need."

Sure. For example, now that the word "community" is used everywhere, what word can we use to talk about the idea of "community" that we used to have?

Yes. You hear people talk about the word "family." The word is changing. Now one could say, "The conditions of life are so different now, that the word in its older meaning is no longer so useful to us so we have to change it." I wouldn't want to be understood to be saying that I'm against linguistic change, or that I don't understand that as conditions change in a culture the meanings of words have to change. And I do understand that technological change certainly speeds that process up. But I think it's dangerous when people are not aware of how this is occurring, or even that it's occurring. So that's the point I wanted to make.

In Technopoly, you use the phrase "technological modesty" to describe King Thamus' response to the invention of writing. How do you avoid having technological modesty turn into pessimism? What are some checks on technological modesty?

The first thing I want to say is that the phrase "technological modesty" really was used by Paul Goodman first. I liked that phrase very much, so I've sort of appropriated it. What I mean by it is a certain sense of restraint in our beliefs about what technology can do for us. For example, let's take medical technology. Certainly everyone would have to say antibiotics have been a great help to humanity. At the same time, we now realize that antibiotics tend to weaken the immune system. Certainly a lot of diseases are showing up, and I don't only mean AIDS. There are others that are coming about because of this weakened immune system. No one had ever heard before of a weakened - no one had even heard of an immune system! But now we know our immune system can be weakened, and that leads to certain diseases.

Now if we had been a little more modest, a little more restrained in our use of antibiotics, and if we didn't think of it as a miracle drug - which is what we called it - we'd be better off. This doesn't mean we're throwing out antibiotics. But American doctors in comparison to European doctors prescribe six times the amount of antibiotics. So that would be an example of a little modesty. Cesarean sections save lives when babies and mothers are at risk-we know this. But now one out of every four births in America come by Cesarean section, and one out of every four pairs of babies and mothers are not at risk. There's a problem, because a Cesarean section is a very serious operation, and a woman is about three times more at risk with a Cesarean section than with a regular vaginal delivery.

So what the term "technological modesty" means — and I don't think it has to lead to pessimism, maybe skepticism, but not cynicism-is that we are technological creatures, but we must never believe that technological innovation and human progress are the same thing. Certainly we must not rest all of our hopes for our future on technology. We have to be more restrained. We have to exercise 
more control over technology wherever that's possible. I mean, television is a spectacular technology, but it's on now in the average American home almost eight hours a day, and the average American high-school graduate will have clocked nineteen thousand hours in front of the television set by high-school's end. That same kid will only have spent thirteen thousand hours in school. That doesn't seem quite balanced. There's a tendency for Americans to allow their technology to take over their lives. When Paul Goodman used the term modesty, that is all he meant, I think, that we really have to take more charge of how we will allow technology to alter our lives.

Speaking of control: I know you like Huxley's Brave New World. If you were to write an updated dystopic vision, how would you write it? What would be the scientific means of control: biology, or something else? What would be principle sources of pleasure, struggle, things like that? If you were to write a Brave New World, how would you set the book up?

First of all I wouldn't call it Brave New World, I would call it Brave New America, so that my novel would be about my own country. And I'm afraid I would have it completely fragmented. People would be living - there'd be like twenty-five nations where there once was one. I would also try to express the idea that a sense of community solidarity and responsibility didn't exist. You know, de Tocqueville worried about this in the early part of the nineteenth century, about individualism, that it could become psychopathic and eventually destroy a nation if people became more and more egocentric. And he didn't foresee the technological developments that we know about. I mean, putting the computer aside just for a moment, look at the music we listen to at home alone, the television we watch at home alone, the radio we hear at home alone, and of course the computers could be home alone. In fact, that movie Home Alone-maybe that's what I'll call my book, Home Alone. Each person, home alone. You know, when I hear people saying computer technology will allow people to vote at home, and shop at home, and bank at home, and so on, they think this is a great thing. But my book would be about the unspoken end of the sentence, which is: "and never have to go see another person outside of their home." I think maybe I'm going to write this book. 